\title{
Russian and International Experience of Private Partner's Civil Guarantees in Public-Private Partnership
}

\author{
Kamil M. Arslanov ${ }^{1}$, Aynur G. Demiyeva ${ }^{2}$, Bulat A. Ponomarev \\ ${ }^{1,2,3}$ Candidate of Juridical Sciences, Associate Professor and Head of the Department of Civil Law of Kazan Federal \\ University (Russian Federation, Kazan) \\ E-mail: $\underline{\text { arslanov-ksu@mail.ru }}^{1} ;+78432036204$ ainuraa@bk.ru $^{2} ;+79033411200$, ponbul@yandex.ru ${ }^{3},+79196833543$
}

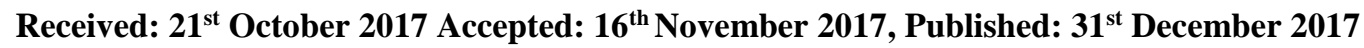

\begin{abstract}
Public-private partnership is a new form of interaction between the subjects of civil turnover, the state and business to achieve joint goals of strategic importance for the economy. The paper is devoted to the legal experience of including in the public-private partnership (hereinafter - PPP) of civil-law guarantees of the private partner rights. The content of such guarantees and rights is disclosed taking into account the existing world and domestic practices, with the focuse on guarantees in the event of unfavorable political and financial-economic circumstances. Particular attention is paid to guarantees against changes in the legal regime during the validity period of a public-private partnership agreement, the ways of their reflection in the law and the shortcomings of the existing domestic legal regulation. It is noted that Russian rulemaking in this area largely corresponds to international standards that establish rules for minimizing the risks of parties within the publicprivate partnership framework. Despite this, there is a need to expand the list of guarantees available in the current legislation based on the experience of the CIS and South-East Asia countries and the relevance of their concretization in relation to the specifics of a particular project. It is proposed to supplement the existing list with currency guarantees, as well as to make changes in the order of actions of the parties to the public-private partnership agreement, with a significant decrease in the expected profit of an investor and a significant increase in the financial burden on it.
\end{abstract}

Keywords: Public-Private Partnership, Agreement, Guarantees, Private Partner, Political Risks, Financial and Economic Risks

\section{Introduction}

Implementation of a project within the framework of public-private partnership agreement is always connected with the risks caused by various (economic, political, technological, etc.) factors [1]. Already at the stage of agreeing on terms of agreement, the parties to the public-private partnership agreement (hereinafter the PPPA, the public-private partnership agreement) should carefully consider minimizing any potential negative consequences that could impede the successful implementation of the project. In this regard, it is important to develop a mechanism for the adequate distribution of legal risks between partners, respecting the balance of private and public interests. A private partner is more prone to such risks, since the main responsibilities under the agreement fall on it, and this is it who carries the key burden in emerging legal relations. In this regard, in the public-private partnership agreement, it is necessary to clearly guarantee the observance of its rights and legitimate interests.

The civil-law nature of these guarantees means that the measures applied to secure them are of a private legal nature. We are talking about the agreement of the parties with special guarantee terms in the agreement itself: on possible requirements for payment of a penalty or amendment of the agreement when it is improperly executed, on the right of a private partner to recover damages caused by the guilty actions of the counterparty, etc.

\section{Materials and Methods}

The presented study is based on the data formulated in domestic and foreign doctrinal and legislative sources. We used general scientific (logical, system-structural, analytical, synthetic) and specific scientific (comparative law) methods.

\section{Results}

In the world practice, there are different types of guarantees for the rights of the participants of publicprivate partnership agreements, depending on the specific conditions of a project, the subject and territorial scope of its implementation, and the specific features of legal regulation. Among them, it is worth highlighting the most common guarantees in a publicprivate partnership agreement.

Guarantees of protection against political risks. They are divided into general and special. The general include such basic provisions of civil law as equality of rights of public and private partners, prohibition of interference in the economic activities of the latter, the absence of discrimination in any form, and protection from expropriation without proportional compensation, The need for legislative consolidation of general guarantees is obvious. It is reflected in international normative acts. For example, the corresponding provision is contained in Annex 2.5 "Practical guidance on effective governance in public-private partnerships" approved by the United Nations Economic Commission for Europe [2]. Following these recommendations, general guarantees were reflected in the national rule-making in Part 3 of Art. 14, part 2 and 4 of Art. 15 of the Federal Law "On Public-Private Partnership, and Municipal-Private Partnership in the 
Russian Federation and Amendments to Certain Legislative Acts of the Russian Federation" (hereinafter - FZ-224) [3].

In the group of special guarantees, the most important is the protection of a private partner from adverse changes in the legal regime during the validity period of a public-private partnership agreement. Thus, in accordance with the Basic Principles of Contemporary Legislation on Concessions of the European Bank for Reconstruction and Development, in order to properly ensure the interests of a private partner in the relevant national laws, it is recommended to make commitments on the unchanged legal regime in force at the time of the agreement (the so-called "stability clause") [4]. However, in domestic legal realities, such a condition seems to be inapplicable, given the current trend towards frequent changes and additions to existing regulatory legal acts.

In this connection, researchers rightly point out that it would be advisable to envisage the possibility of making appropriate amendments to the agreement in the event of unfavorable factors. This is the traditional principle for the civil legislation of the CIS and the continental law of changing the contract due to a significant change in circumstances [5, p. 219]. This fully agrees with the provisions of Part 1 of Art. 451 of the Civil Code of the Russian Federation [6], according to which a significant change in the circumstances from which the parties proceeded when concluding the contract, is the basis for its amendment or termination, unless otherwise provided by the contract or follows from its substance.

The Russian legislator followed the path of enshrinement in Part 5 of Art. 15, FZ-224 of the rights of the parties to adjust the conditions of a publicprivate partnership agreement in such "essential" circumstances. For example, a public partner is obliged to apply measures to support a private partner if changes in the legal regime have led to an increase in the aggregate tax burden on the latter and other worsening of its situation compared to that it was before the relevant changes took effect, in connection with which it has been deprived of that it was entitled to expect when concluding the agreement. A prolongation of the public-private partnership agreement period, the increase by the public partner of the amount of financial security or its total costs for the project implementation are envisaged in the capacity of compensation measures.

Exceptions to this rule are cases of adoption of federal laws changing the situation of the parties in order to protect the foundations of the constitutional system, ensure the country's defense and state security, and also introduce changes in technical rules and regulatory acts governing relations for the mineral wealth conservancy, environment and health protection (Parts 6 and 7 of Art. 15 FZ-224). A similar wording is found in the national legislation of some countries (for example, Belarus and Moldova) [7]. Although the Model Law on public-private partnership, adopted as a model for the CIS countries, such a reservation is not provided [8].
This causes some concern. Given the current political situation in the country, it can be assumed that any change in the legislation that is unfavorable for an investor will be treated, if necessary, as protective and taken in defense of the rights and legitimate interests of citizens and the state. In this regard, it seems necessary to specify the provisions of the analyzed parts of Article 15 of the Federal Law-224, indicating the need to include in the text of a public-private partnership agreement a list of cases in which such a change in legislation will be relevant for the project being implemented, taking into account its specifics.

Guarantees against financial and economic risks. Given the long-term nature of a public-private partnership agreement, it is impossible to foresee in advance all cases in which the conditions for project implementation change significantly. The devaluation of the national currency, which has a tendency to increase in inflation, the unpredictable change in the interest rates on loans by credit and banking institutions is only a small part of the likely negative events. Certain part of them, of course, is included in the financial and economic justification of a publicprivate partnership project, but there always remains the part that it is not always possible to reasonably foresee.

In the world practice, there are various types of prevention of financial and economic risks in publicprivate partnership projects. For example, in Tanzania, the state guarantees attraction of new sources of financing in case of insolvency of a public partner within the framework of its contractual obligations [9, p. 20-21]. Legislation of Pakistan allows a public partner to guarantee the investor risks of depreciating the national currency, what is especially important in the unstable economy of developing countries [10]. A guide to the development of public-private partnership infrastructure projects under the public-private partnership of the United Nations Economic and Social Commission for Asia and the Pacific (UNESCAP) establishes the obligation of a public partner to buy out a public-private partnership project in the event of a long-term force majeure event, with compensation to the private investor of all costs incurred by it [11]. In Kazakhstan, the state provides a private partner with guarantees on infrastructure bonds issued for publicprivate partnership projects in the field of transport [12].

In the Republic of Korea, a private partner is provided with a list of possible tools to ensure the stable implementation of a project. The state provides financial support in the form of granting subsidies for the construction of facilities according to the agreement and the issuance of long-term loans. If the profit received by the private partner is less than anticipated at the conclusion of the agreement, the government covers the amount of the deficit [13].

Among the guarantees of this category, the FZ-224 expressly provides for the possibility of reviewing regulated prices (tariffs) and allowances to them for goods sold by the investor in the public-private partnership agreement, to the work and services 
provided, if they do not correspond to the parameters originally laid in the project. In such cases, the private partner has the right to demand changes in the agreement.

However, in general terms, the conditions for reviewing the agreement under the influence of unfavorable financial and economic factors in FZ-224 have not been established. Therefore, it seems reasonable to supplement article 15 of the law with the rule that a private partner has the right to demand changes in the terms of a public-private partnership agreement if the cost of fulfilling the obligations has significantly increased or the expected profit has significantly decreased compared to the originally expected costs and profit. A similar norm is contained in the special law on public-private partnership of the Republic of Tajikistan [14].

In doing so, it is necessary to take into account the provisions of the UNCITRAL Legislative Guide on Privately Financed Infrastructure Projects, according to which the use of compensatory measures in the event of negative financial and economic events should be reasonably limited [15]. Otherwise, the budget burden may increase so that further implementation of the project will become burdensome for the public partner. Therefore, it seems right to define in the law a restrictive percentage of the cost of the project projected by public-private partnership agreement, above which the partners have the right to raise the issue of the expediency of further implementation of the project.

Performance guarantees by a public partner. They help to protect the investor from the risks associated with the counterparty's default. The most frequently used types are the guarantees of purchase by a public partner of goods and services created by a private partner during the performance of the public-private partnership agreement, and the supply by a public partner of the goods necessary for the implementation of the project. It would be logical to use such conditions in the practice of concluding a publicprivate partnership agreement if the subject matter of the agreement includes corresponding obligations.

The performance guarantees should also include the obligation of the public partner to assist in obtaining permits and approvals of authorized bodies that are binding for achieving the agreement's objectives (part 10, art. $15 \mathrm{FZ}-224)$. In fact, this rule establishes the principle of cooperation between the parties, which, in particular, has already been implemented in contractual legal relations.

Other guarantees. In addition to those mentioned above, there are also used in world practice other types of guarantees which can be used in domestic conditions. In accordance with Part 9 of Art. 15 FZ224, public-private partnership agreements may establish additional guarantees of the rights of a private partner, not inconsistent with the law. According to some researchers, the possibility of establishing them testifies to the existence of civil-law relations within the framework of a public-private partnership [16, $\mathrm{p}$. 34].
A condition on currency guarantees is seems economically expedient. It is implemented in the following forms: convertibility of profits in foreign currency, possibility to transfer currency abroad, and the availability of any foreign currency [2]. Thus, the legislation of the Socialist Republic of Vietnam provides for the right of a private partner to freely acquire foreign currency for the needs of a publicprivate partnership project [17, p. 159]. In Chile, investors could have compensation for losses with a significant change in the exchange rate [17, p. 29]. For a private partner, this, of course, is an opportunity to attract international financial institutions unimpeded for the implementation of the project.

\section{Summary}

Domestic legislation as a whole reflects the existing world practice of normative regulation of basic civil and legal guarantees of private partner rights related to political and financial and economic risks. However, a reasonable legislative expansion of the list of such guarantees will increase the investment attractiveness of the public-private partnership institution.

\section{Conclusion}

The current norms of the domestic legislation providing for guarantees of the rights of a private partner require addition of some details and refinement. This is due to the fact that FZ-224 entered into force only on January 1, 2016, therefore, for such a short period, it has not been formed the necessary contractual practice of the use of public-private partnership agreements, the analysis of which would allow making sufficient generalizations to propose changes to this law.

\section{References}

1. European PPP Expertise Centre: State Guarantees in PPPs. A Guide to Better Evaluation, Design, Implementation and Management. 2011, 36 c. URL: http://www.eib.org/epec/resources/epec-stateguarantees-in-ppps-public

2. United Nations Economic Commission for Europe: Guidebook on promoting a good governance in public-private partnerships / United Nations. New York, Geneva. 2008. URL: http://www.unece.org/fileadmin/DAM/ceci/publication s/ppp.pdf

3. Federal Law No. 224-FZ dated July 13, 2015 "On Public-Private Partnership, Municipal-Private Partnership in the Russian Federation and Amendments to Certain Legislative Acts of the Russian Federation" // Rossiyskaya Gazeta. - 17.07.2015. - No. 156.

4. EBRD Core Principles for a Modern Concession Law 2006 // URL: http://www.ebrd.com/russian/downloads/legal/concessi ons/russian.pdf.

5. Public-private partnership in Russia and foreign countries: legal aspects / S.A. Belov, E.V. Gritsenko, D.A. Zhmulina and others; Ed. by V.F. Popondopulo, N.A. Shevelyovoy. Moscow: Infotropic Media, 2015. 528 p. 
6. The Civil Code of the Russian Federation (Part One) of 30.11.1994 No. 51-FZ (as amended on 03.07.2016) (as amended, entered into force on 01.08.2016) // Meeting of the legislation of the Russian Federation. 12/05/1994. No. 32. Art. 3301.

7. See: Law of the Republic of Belarus No. 345-3 of 30.12.2015 "On public-private partnership" // URL:

http://www.pravo.by/document/?guid=12551\&p0=H11 $500345 \& p 1=1$; Law of the Republic of Moldova No. 179 of 10.07.2008 "On public-private partnership" // URL:

http://lex.justice.md/viewdoc.php?id=328990\&lang=2 8. Model Law on Public-Private Partnership (Adopted in St. Petersburg on 11/28/2014 by Resolution No. 41-9 at the 41st plenary meeting of the Interparliamentary Assembly of CIS Member States) // http://www.parliament.am/library/modelayin\%20orenq ner/305.pdf

9. Eric Frank Ringo Termination Compensation and State Concessions (Guarantees) under the PublicPrivate Partnership (PPP). Towards Tanzania new PPP horizon. $2011, \quad 69 \quad$ c. $\quad$ URL: http://www.gbv.de/dms/buls/668435526.pdf

10. Risk management manual for Public Private Partnership in infrastructure. Government of Punjab, Planning \& Development Department. 2011. URL: http://ppp.punjab.gov.pk/sites/ppp.pitb.gov.pk/files/Ris k_Management_Guidelines.pdf

11. A guidebook on Public-Private Partnership in infrastructure, UNESCAP, 2011. URL: http://www.unescap.org/sites/default/files/ppp_guidebo ok.pdf
12. Public-Private Partnership Reference Guide V.2, 2014, International Bank for Reconstruction and Development / The World Bank, Asian Development Bank, and Inter-American Development Bank. URL: http://api.ning.com/files/Iumatxx-

0jz3owSB05xZDkmWIE7GTVYA3cXwt4K4s3Uy0Nt PPRgPWYO11LrWaTUqybQeTXIeuSYUxbPFWlysuy NI5rL6b2Ms/PPPReferenceGuidev02Web.pdf

13. South Korea, Ministry of Strategy and Finance: Basic Plan for Public-Private Partnerships / Seoul, $2010 . \quad$ URL: http://www.kdi.re.kr/kdi_eng/kdicenter/pimac_main.js $\mathrm{p}$

14. The Law of the Republic of Tajikistan "On Public-Private Partnership" dated December 13, 2012 No. 439 // URL: http://medt.tj/documents/main/normativno-pravovieakti/zakonodatelnie-akti/en/02540-en.pdf

15. UNCITRAL: Legislative Guide on Privately Financed Infrastructure Projects / United nations. New York, $2011 . \quad$ URL: http://www.uncitral.org/pdf/english/texts/procurem/pfi p/guide/pfip-e.pdf

16. Chepurnov A.A. Concession as an organizational and legal form and method of state management of the economy // Economy, Labor, Law.2015. № 3. - P. 29-36.

17. Investment Experts' Group (IEG): Guidebook on PPP Frameworks in APEC Region / Indonesia. 2013, 169 c. URL: http://media.rspp.ru/document/1/9/3/93732c52b36f750 a125f90471486bda0.pdf 